\title{
API ZYM: a simple rapid system for the detection of bacterial enzymes
}

\author{
M. W. HUMBLE, ANNA KING, AND IAN PHILliPS 1 \\ From the Department of Microbiology, St. Thomas's Hospital Medical School, London SE1 7EH
}

SUMMARY The API ZYM system of detection of enzymes has been applied to 81 bacteria belonging to several species. It was found to be easy to use and has produced results that may be useful in the identification of a variety of bacteria.

Most of the methods used in clinical microbiology laboratories for the identification of bacteria require growing organisms and detect the end result of complex metabolic activities. An alternative is to use a single substrate and a heavy inoculum of organism that need not grow to detect specific enzymes. The Auxotab system for detecting esterases, lipases, peptidases, and other enzymes, described by Buissière et al. (1967), makes use of this alternative approach. It has been modified and made commercially available as the API ZYM system (API Laboratory Products Ltd, Philpot House, Rayleigh, Essex) which makes it possible to detect the activity of enzymes on 19 substrates within four hours. This paper reports a preliminary assessment of the API ZYM system in the identification and typing of a selection of medically important bacteria.

\section{Methods and materials}

The API ZYM system (Figure) consists of a plastic gallery of cupules, in the bottom of each of which is a fabric support carrying the substrates and buffer. These substrates detect the following enzymes: alkaline and acid phosphatases, butyrate esterase, caprylate esterase lipase, myristate lipase, leucine, valine and cystine aminopeptidases, trypsin, chymotrypsin, phosphoamidase, $\alpha$-galactosidase, $\beta$-galactosidase, $\beta$-glucuronidase, $\alpha$-glucosidase, $\beta$-glucosidase, $\beta$-glucosaminidase, $\alpha$-mannosidase, and $\alpha$-fucosidase.

The organisms to be tested were grown on blood agar plates, and a suspension was made in peptone water to an opacity equivalent to that of a McFarland No. 5 standard. Some of the organisms

\footnotetext{
${ }^{1}$ Requests for reprints should be addressed to IP Received for publication 25 August 1976
}

were ultrasonicated for 5 minutes at an amplitude of $22 \mu \mathrm{m}$ in an ultrasonic disintegrator (MSE Mk 2 150 watts). During the process the bottle was placed in iced water. An API ZYM gallery was placed in its humidification chamber (to which distilled water had been added), and $0.04 \mathrm{ml}$ volumes of bacterial suspension or ultrasonicate were placed in each cupule. After incubation at $37^{\circ} \mathrm{C}$ for 4 hours $0.02 \mathrm{ml}$ of fresh colour reagent containing $20 \mathrm{mg}$ Fast Blue BB (Sigma F0250) in $10 \mathrm{ml}$ was added to each cupule, and the gallery was kept in the dark for 5 minutes and then exposed for 30 seconds under a 750-watt lamp to prevent non-specific yellowing of the colour reagent. The reactions were then graded $0-5$, depending on the intensity of colour compared with representations on a colour chart.

The strains of bacteria investigated were isolated in the Department of Microbiology, St. Thomas' Hospital, but some of the streptococci were provided by the Streptococcus Reference Laboratory of the Public Health Laboratory Service, Colindale. The 81 isolates consisted of Streptococcus faecalis (7), Strep. bovis (4), Strep. mutans (3), Strep. sanguis (8), Strep. mitior (7), Strep. milleri (10), Staphylococcus aureus (2), coagulase-negative staphylococci sensitive (5) or resistant (4) to novobiocin, Pseudomonas aeruginosa (2), P. putida (2), P. fluorescens (2), P. cepacia (2), $P$. thomasii (1), $P$. acidovorans (1), $P$. pseudoalcaligenes (1), $P$. stutzeri (1), P. maltophilia (1), Acinetobacter lwoffii (2), A. anitratus (1), Proteus mirabilis (1), Pr. vulgaris (2), Pr. morganii (2), Pr. rettgeri (2), Providencia stuartii (2), Escherichia coli (2), Klebsiella aerogenes (2), and Serratia marcescens (2).

\section{Results}

The method worked well but the absence of organisms with known reactions in the system made 


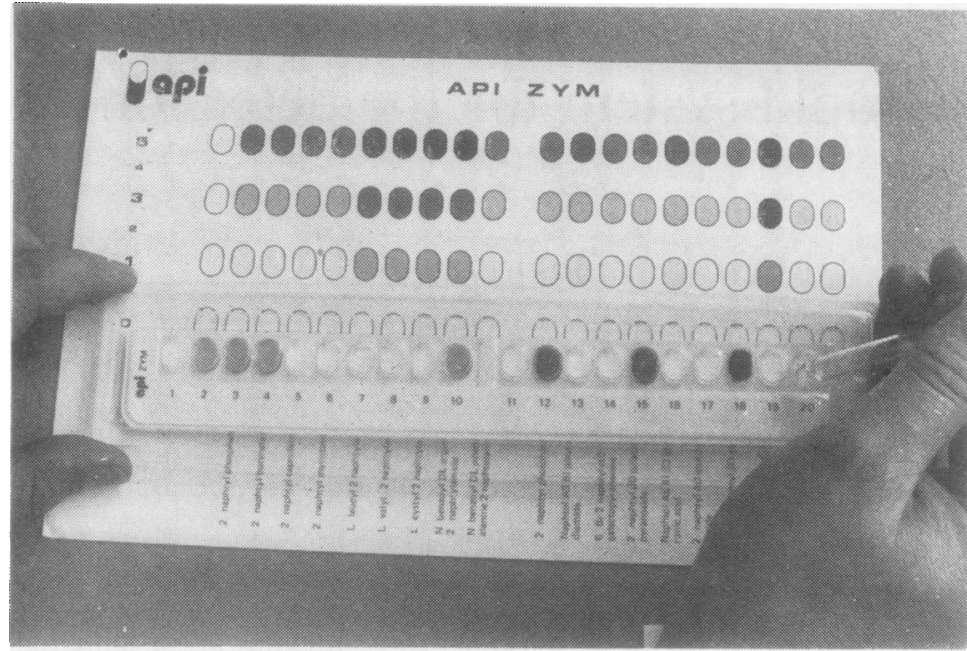

Figure The API ZYM system for the detection of enzymes.

realistic control impossible. None of the 81 organisms had valine or cystine aminopeptidases, $\alpha$-mannosidase or $\alpha$-fucosidase. None of the Gram-positive organisms had trypsin, chymotrypsin or $\beta$-glucosaminidase, none of the Gram-negative fermenters had chymotrypsin, and none of the non-fermenters had $\alpha$-galactosidase, $\beta$-galactosidase, $\beta$-glucosidase, or $\beta$-glucosaminidase.

\section{STAPHYLOCOCCI}

Staphylococcus aureus and novobiocin-sensitive coagulase-negative staphylococci both produced acid and alkaline phosphatases, butyrate esterase, and caprylate esterase lipase. The colour reaction of acid and alkaline phosphatases developed more rapidly with Staph. aureus. The novobiocin-resistant coagulase-negative staphylococci did not produce acid phosphatase, and only two showed weak alkaline phosphatase activity.

\section{STREPTOCOCCI}

Only Strep. faecalis constantly produced caprylate esterase lipase. Strep. milleri was characterised by strong production of acid and alkaline phosphatase, whereas neither Strep. faecalis nor Strep. bovis produced alkaline phosphatase and had only weak acid phosphatase activity. In addition, Strep. faecalis differed from Strep. bovis in failing to produce leucine aminopeptidase and $\alpha$-galactosidase.

In the 'viridans' group, only one isolate, of Strep. mitior, produced alkaline phosphatase and only two produced acid phosphatase. The one isolate of Strep. mitior that produced both also produced dextran. Six of the eight isolates of Strep. sanguis produced acid phosphatase. The four isolates that produced alkaline phosphatase also produced acid phosphatase $\stackrel{\widehat{\rho}}{\mathcal{S}}$ and $\alpha$-glucosidase, the latter in contrast with the four $\vec{\varphi}$ isolates that did not produce alkaline phosphatase. The Strep. mutans isolates produced $\alpha$-glucosidase but not acid nor alkaline phosphatase. Detailed results are shown in the Table.

GRAM-NEGATIVE ORGANISMS

As yet too few organisms have been examined to $\stackrel{\mathbb{Q}}{\varrho}$ enable identification of characteristic patterns. How- $\overrightarrow{\overrightarrow{0}}$ ever, the isolates of $E$. coli, Klebsiella spp, and 3 Serratia spp all had strong $\beta$-galactosidase and leucine aminopeptidase activity. Other fermenters showed differences particularly in glucosidase patterns. Among the non-fermenters, caprylate esterase lipase and leucine aminopeptidase were common. $P$. aeruginosa, $P$. cepacia, and Acinetobacter spp usually had strong myristate lipase activity, and $P$. maltophilia produced alkaline phosphatase and trypsin. Few of the non-fermenters had any activity on the carbohydrate substrates.

ULTRASONICATES

There was no difference in the enzyme detected in $N$ intact and ultrasonicated cells among Gram-positive organisms comprising one isolate of Strep. faecalis, two of Strep. bovis, five of Strep. sanguis, one of Strep. milleri, two of Staph. aureus, and four of Staph. albus. Among Gram-negative organisms, there was a clear and sometimes total loss of leucine aminopeptidase activity in each single strain examined of $P$. aeruginosa, Acinetobacter anitratus, Proteus mirabilis, E. coli, $K$. aerogenes, Ent. cloacae, and occasionally the activity of other enzymes was diminished. 
Table Enzyme activity of non-haemolytic and a haemolytic streptococci

\begin{tabular}{|c|c|c|c|c|c|c|c|c|c|c|}
\hline & \multicolumn{10}{|c|}{ Number of isolates with } \\
\hline & \multirow{2}{*}{$\begin{array}{l}\text { Alkaline } \\
\text { phos- } \\
\text { phatase }\end{array}$} & \multirow{2}{*}{$\begin{array}{l}\text { Acid } \\
\text { phos- } \\
\text { phatase }\end{array}$} & \multirow{2}{*}{$\begin{array}{l}\text { Butyrate } \\
\text { esterase }\end{array}$} & \multirow{2}{*}{$\begin{array}{l}\text { Caprylate } \\
\text { esterase } \\
\text { lipase }\end{array}$} & \multirow{2}{*}{$\begin{array}{l}\text { Leucine } \\
\text { amino- } \\
\text { peptidase }\end{array}$} & \multirow{2}{*}{$\begin{array}{l}\text { Phospho- } \\
\text { amidase }\end{array}$} & \multicolumn{2}{|c|}{ Galactosidase } & \multicolumn{2}{|c|}{ Glucosidase } \\
\hline & & & & & & & $\alpha$ & $\beta$ & $\alpha$ & $\boldsymbol{\beta}$ \\
\hline $\begin{array}{l}\text { Strep. faecalis (7) } \\
\text { Strep. bovis (4) } \\
\text { Strep. mutans (3) } \\
\text { Strep. sanguis (8) } \\
\text { Strep. mitior (7) } \\
\text { Strep. miller (10) }\end{array}$ & $\begin{array}{l}0 \\
0 \\
0 \\
2,2 \\
0,1 \\
10,0\end{array}$ & $\begin{array}{c}1,6^{1} \\
0,4 \\
0 \\
4,2 \\
1,1 \\
10,0\end{array}$ & $\begin{array}{l}2,5 \\
0,1 \\
0,2 \\
0,6 \\
1,5 \\
0,9\end{array}$ & $\begin{array}{l}3,4 \\
0,1 \\
0 \\
0 \\
0,1 \\
0\end{array}$ & $\begin{array}{l}0 \\
0,4 \\
0,1 \\
4,4 \\
5,2 \\
5,5\end{array}$ & $\begin{array}{l}3,3 \\
0,1 \\
0 \\
0 \\
0 \\
0,1\end{array}$ & $\begin{array}{l}0 \\
3,1 \\
0 \\
1,3 \\
4,2 \\
0,2\end{array}$ & $\begin{array}{l}0 \\
0 \\
0 \\
1,1 \\
1,1 \\
0,2\end{array}$ & $\begin{array}{l}6,1 \\
2,2 \\
1,2 \\
2,2 \\
1,4 \\
0,7\end{array}$ & $\begin{array}{l}6,0 \\
3,1 \\
0 \\
0 \\
0 \\
0,2\end{array}$ \\
\hline
\end{tabular}

${ }^{1}$ The first figure is the number of isolates with strong activity (3-5), and the second the number with weak (1-2) activity.

\section{Discussion}

The main purpose of this preliminary investigation into the API ZYM system was to assess the feasibility of its use in a routine microbiology laboratory. The method was easy to set up, requiring no special apparatus or reagents other than those supplied (in view of the finding that ultrasonication resulted in the detection of fewer enzymes) and results for a wide variety of organisms were easy to read and repeatable. We concluded that the system would be easy to use in any clinical microbiology laboratory.

The actual value of the method requires further investigation. The original Auxotab system described by Buissière et al. (1967) has been found to be useful in taxonomic studies on staphylococci and micrococci, Escherichia, Bacillus, and Brucella species (Joubert and Buissière, 1969; Peny and Buissière, 1970). A similar method, in which fluorescent methylumbelliferone is released from non-fluorescent compounds by specific enzyme activity, has been briefly described by Maddocks and Greenan (1975). This too, it has been suggested, might be useful in taxonomic and epidemiological studies. We have made a brief assessment of the umbelliferone method detecting $\mathrm{N}$-acetyl- $\beta$-D-glucosaminidase, $\mathrm{N}$-acetyl$\beta$-D-galactosaminidase, $\beta$-D-galactosidase, $\beta$-Dglucosidase, acid and alkaline phosphatases, and $\alpha$-L-arabino-pyranosidase, and have come to similar conclusions.
Our preliminary results with the API ZYM system suggest that it could be as useful as the Auxotab and umbelliferone methods for the detection of specific enzyme activity, and that the patterns of activity could be useful in the taxonomy and typing of bacteria. We have demonstrated interesting and, within the limits of the study, consistent differences in the activity of various streptococci and staphylococci, and there are results of sufficient interest among Gram-negative bacilli to suggest that further study might be fruitful. It is not clear whether the use of a nutrient substrate allows the detection of constitutive and inducible enzymes.

We thank API Laboratory Products Ltd for supplies of API ZYM strips.

\section{References}

Buissière, J., Fourcard, A., and Colobert, L. (1967). Usage de substrats synthétiques pour l'étude de l'équipement enzymatique de microorganismes. Comptes rendus Hebdomaires des séances de l'Academie des Sciences [D], 264, 415-417.

Joubert, L. and Buissière, J. (1969). Le chimiotype bactérien en épidémiologie. Bulletin de l'Académie Vétérinaire de France, 42, 81-91.

Maddocks, J. L. and Greenan, M. J. (1975). A rapid method for identifying bacterial enzymes. Journal of Clinical Pathology, 28, 686-687.

Peny, J. and Buissière, J. (1970). Microméthode d'identification des bactéries. Annales de l'Institut Pasteur, 118, 10-18. 